\title{
Selection of Alternative $\mathrm{G}_{\mathrm{i}}$-mediated Signaling Pathways at the Dopamine $\mathrm{D}_{2}$ Receptor by Protein Kinase $\mathrm{C}$
}

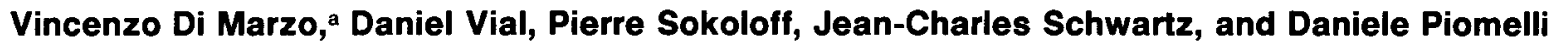 \\ Unité de Neurobiologie et Pharmacologie de l'INSERM, Paris 75014, France
}

\begin{abstract}
Evidence indicates that a single membrane receptor subtype may be responsible for the generation of multiple intracellular signals, but mechanisms allowing for the selection of a specific effector pathway have not yet been documented. In neurons and other cells, the stimulation of dopamine $D_{2}$ receptors produces, via G-protein activation, a spectrum of intracellular responses including inhibition of adenylyl cyclase activity, modulation of $\mathrm{K}^{+}$currents, and potentiation of $\mathrm{Ca}^{2+}$-evoked arachidonic acid (AA) release. In this study, we report that, in Chinese hamster ovary cells, stimulation of protein kinase $\mathbf{C}$ (PKC) directs the preferential coupling of transfected $D_{2}$ receptors from inhibition of adenylyl cyclase to potentiation of AA release, two responses mediated by $G_{i}$. The switch between these two signaling systems is accompanied by marked changes in their GTP sensitivities, indicating that it may result from the phosphorylation of component(s) of the receptor- $\mathrm{G}_{i}-$ protein complex. Brain PKC activity is enhanced by neurotransmitters and by neuronal depolarization. Thus, the ability of this protein kinase to remodel signaling pathways at the $D_{2}$ receptor may regulate these $\mathrm{G}_{\mathrm{i}}$-mediated responses in an activity-dependent manner, and represent a novel form of synaptic plasticity.
\end{abstract}

IKey words: Chinese hamster ovary fibroblasts, transfected cells, second messengers, arachidonic acid, phospholipase $A_{2}$, CAMP, adenylyl cyclase]

Communication between neurons requires that the actions of neurotransmitters on their target cells be both specific and modifiable, to allow for plastic changes to occur in response to environmental demands. To achieve specificity, many neurotransmitters interact with distinct subtypes of membrane receptors coupled to specific intracellular second messengers. For example, dopamine, a major modulatory transmitter in the brain, exerts its neural actions through stimulation of at least five receptor subtypes, discretely distributed throughout the CNS, and functionally coupled either to $\mathrm{G}_{\mathrm{s}}$-mediated activation of adenylyl cyclase ("D $D_{1}$ type") or to $G_{i}$-mediated cyclase inhibition ("D $D_{2}$ type") (Sibley and Monsma, 1992; Schwartz et al., 1992).

\footnotetext{
Received Dec. 11, 1992; revised May 3, 1993; accepted May 20, 1993.

D.P. was supported in part by a Young Investigator Award from the National Alliance for Research on Schizophrenia and Depression (NARSAD), and V.D., by a fellowship from the European Molecular Biology Organization. We thank Dr. J.-A. Girault for critical reading of the manuscript.

Correspondence should be addressed to Daniele Piomelli, Unité de Neurobiologie et Pharmacologie de l'INSERM, 2ter Rue d'Alésia, Paris 75014, France.

a Present address: Istituto per la Chimica di Molecole d'Interesse Biologico, CNR, via Toiano 6, Arco Felice, Napoli 80072, Italy.

Copyright (C) 1993 Society for Neuroscience $0270-6474 / 93 / 134846-08 \$ 05.00 / 0$
}

Increasing evidence indicates, however, that a single receptor subtype may be linked to the formation of multiple, parallel intracellular signals. This spectrum of heterogeneous effectors may be produced through activation of one or several transducing G-proteins (for review, see Spiegel, 1992). For example, in anterior pituitary cells, two different $G$-proteins, $G_{0}$ and $G_{i 3}$, link $\mathrm{D}_{2}$ receptors to modulation of $\mathrm{Ca}^{2+}$ and $\mathrm{K}^{+}$channel opening, respectively (Lledo et al., 1992). Likewise, in Chinese hamster ovary $(\mathrm{CHO})$ cells transfected with $\mathrm{D}_{2}$ receptor cDNA $\left[\mathrm{CHO}\left(\mathrm{D}_{2}\right)\right], \mathrm{D}_{2}$ receptor stimulation causes both inhibition of adenylyl cyclase activity and facilitation of evoked release of arachidonic acid (AA) via pertussis toxin-sensitive $G_{i}$-proteins (Felder et al., 1991; Kanterman et al., 1991; Piomelli ct al., 1991).

The functional redundancy in intracellular signaling underscored by these findings raises several important questions. Are all the signals driven by a single receptor subtype equally operative under all circumstances? Or rather, are these signals subject to cellular mechanisms of integration and regulation? Can the spectrum of second messengers in a cell be remodeled, for example, by changing the functional weight of one pathway with respect to others, to adapt to its varying needs? And if this is the case, could such a remodeling at the second messenger level affect the response to receptor stimulation? Interest in such questions lies in the possibility that, like ion channels and neurosecretory mechanisms, the pathways of transmembrane signaling may represent a potential substrate for plastic changes in neural cells.

Protein kinase $\mathrm{C}(\mathrm{PKC})$ serves important regulatory functions in the CNS, where it is thought to participate in the modulation of ion channel activity, receptor desensitization and transmitter release (Nishizuka, 1988). Using $\mathrm{CHO}\left(\mathrm{D}_{2}\right)$ cells, we have now examined the role played by this protein kinase in controlling parallel intracellular signaling at the $\mathrm{D}_{2}$ receptor. We report that activation of $\mathrm{PKC}$ switches the coupling of $\mathrm{D}_{2}$ receptors from inhibition of adenylyl cyclase toward facilitation of AA release, possibly by phosphorylating component(s) of the receptor $-\mathrm{G}_{\mathrm{i}}$ protein complex. Because brain PKC activity is stimulated by neurotransmitters and neuronal depolarization (Nishizuka, 1988), the results suggest that remodeling of transmembrane signaling pattern by this protein kinase, demonstrated here in an heterologous expression system, may modify in an activitydependent manner physiological responses to $\mathrm{D}_{2}$ receptor stimulation.

\section{Materials and Methods}

Cell culture and transfections. CHO cells were transfected with rat $D_{2(4+4)}$ receptor (also termed $\mathrm{D}_{2 \mathrm{~L}}$ ) cDNA or with human $\mathrm{D}_{2(4,5)}$ receptor (also termed $\mathrm{D}_{2 \mathrm{~S}}$ ) cDNA as previously described (Giros et al., 1989). $\mathrm{CHO}$ 
cells expressing rat $D_{2(444)}$ receptor are referred to in the text as $\mathrm{CHO}\left(\mathrm{D}_{2}\right)$; those expressing $\mathrm{D}_{2(415)}$ receptor, as $\mathrm{CHO}\left(\mathrm{D}_{2(415)}\right)$. Transfected clones were maintained in monolayer culture in Dulbecco's Modified Eagle's Medium (DMEM) supplemented with $10 \%$ fetal calf serum (GIBCO) at $37^{\circ} \mathrm{C}$ in $5 \% \mathrm{CO}_{2} . \mathrm{CHO}\left(\mathrm{D}_{2}\right)$ expressed $1.3 \times 10^{5}$ receptors/cell, and $\mathrm{CHO}\left(\mathrm{D}_{2(415)}\right), 1.5 \times 10^{5}$ receptors/cell.

Receptor binding. $\mathrm{CHO}\left(\mathrm{D}_{2}\right)$ cells were incubated in DMEM containing $0.25 \%$ trypsin (GIBCO) for $5 \mathrm{~min}$ at room temperature, and the reaction was stopped by adding $10 \mathrm{ml}$ of supplemented DMEM. Detached cells were collected by centrifugation and washed in $15 \mathrm{~mm}$ Tris- $\mathrm{HCl}, \mathrm{pH}$ 7.4 , containing $5 \mathrm{~mm} \mathrm{MgCl}$ and $10 \mathrm{~mm}$ sodium pyrophosphate, to inhibit protein phosphatase activity. After cell disruption, membranes were isolated by centrifugation $(50,000 \times g$ for $15 \mathrm{~min})$ in the same buffer. Binding was determined in $50 \mathrm{~mm}$ Tris- $\mathrm{HCl}, \mathrm{pH} 7.4$, containing (mM) $\mathrm{NaCl}, 120 ; \mathrm{KCl}, 5 ; \mathrm{CaCl}_{2}, 2 ; \mathrm{MgCl}_{2}, 2$; ascorbic acid, 0.28; and 8-hydroxyquinoline, 0.1 . Curves were analyzed by computerized nonlinear regression using a one- or two-site model (Martres et al., 1984).

${ }^{3} \mathrm{H}$-AA release. Cells (24-well plates) were labeled by incubation with ${ }^{3} \mathrm{H}$-AA (Amersham; $\left.200-220 \mathrm{Ci} / \mathrm{mmol}, 0.25 \mathrm{mCi} / \mathrm{ml}\right)$ in DMEM $(1 \mathrm{ml})$ containing $0.2 \%$ bovine serum albumin (BSA) for $2 \mathrm{hr}$ at $37^{\circ} \mathrm{C}$. To eliminate unincorporated radioactivity, cells were washed with $1 \mathrm{ml}$ of DMEM plus BSA, before incubating them for $30 \mathrm{~min}$ at $37^{\circ} \mathrm{C}$ in $1 \mathrm{ml}$ of DMEM, containing final concentrations of the appropriate drugs. Analysis by high-performance liquid chromatography revealed that, in BSA-containing incubations, free ${ }^{3} \mathrm{H}$-AA constituted more than $90 \%$ of the released radioactivity in both control and stimulated samples (Di Marzo and Piomelli, 1992). To prevent dopamine oxidation, incubations with the drug were carried out in the presence of ascorbic acid $(0.1 \%)$, which did not affect either basal or stimulated ${ }^{3} \mathrm{H}-\mathrm{AA}$ rclcasc (not shown). In some experiments, cells were incubated with pertussis toxin $(200 \mathrm{ng} / \mathrm{ml})$ for $4 \mathrm{hr}$ at $37^{\circ} \mathrm{C}$ in $1 \mathrm{ml}$ of DMEM. Incubation with the toxin did not affect ' $\mathrm{H}$-AA labeling of phospholipids (not shown). ${ }^{3} \mathrm{H}-\mathrm{AA}$ release was determined by liquid scintillation counting of samples $(0.5 \mathrm{ml})$ of the incubation medium.

cAMP formation. Cells (96-well plates) were incubated for $10 \mathrm{~min}$ in $0.15 \mathrm{ml}$ in DMEM containing isobutylmethylxanthine (IBMX) $(0.1 \mathrm{mM})$, a phosphodiesterase inhibitor, plus forskolin $(10 \mu \mathrm{M})$ and final concentrations of the appropriate drugs. After extraction in $0.1 \mathrm{M} \mathrm{HCl}(0.1$ $\mathrm{ml}$ ), sonication and neutralization of the tissue extracts, cAMP concentrations were determined using a radioimmunoassay kit (Amersham), following the manufacturer's instructions.

Measurements of intracellular free $\mathrm{Ca}^{2+}$ concentration. Cells were suspended by treatment with trypsin (see above), and incubated for 60 min at $37^{\circ} \mathrm{C}$ of DMEM containing BSA $(0.2 \%)$ and fura- 2 acetoxymethyl ester $(1 \mu \mathrm{M})$. After washing, cells were resuspended in HEPES-buffered Krebs' solution (containing, in mmol/liter, $\mathrm{NaCl}, 125 ; \mathrm{KCl}, 5 ; \mathrm{KH}_{2} \mathrm{PO}_{4}$ and $\mathrm{MgSO}_{4}, 1.2 ; \mathrm{CaCl}_{2}, 2$; glucose, 6; HEPES/ NaOH buffer, $\mathrm{pH} 7.4$ ) and $\mathrm{Ca}^{2+}$ levels were determined by using a Hitachi F-2000 fluorescence spectrophotometer (Grynkiewicz et al., 1985).

Permeabilized cells. $\mathrm{CHO}\left(\mathrm{D}_{2}\right)$ cells in 24-well plates were washed twice with $1 \mathrm{ml}$ of Spinner MEM (with Earl's salts, without glutamine; GIBCO) with $0.2 \%$ BSA, and incubated in $1 \mathrm{ml}$ of the same medium containing $50 \mu \mathrm{g} / \mathrm{ml}$ saponin plus final concentrations of drugs. At least $90 \%$ of the cells became permeable to trypan blue within $5 \mathrm{~min}$ of saponin treatment. For ${ }^{3} \mathrm{H}$-AA release experiments, cells were previously labeled for $2 \mathrm{hr}$ as described above and unincorporated radioactivity eliminated by washing.

Statistical analysis. Results are expressed as mean \pm SEM of $n$ experiments. $\mathrm{EC}_{50}$ and $\mathrm{IC}_{50}$ values were calculated by nonlinear regression analysis, using data obtained from at least three separate experiments. Statistical comparisons between means \pm SEM were carried out using analysis of variance, unless otherwise indicated.

Materials. $\mathrm{Ca}^{2+}$ ionophore A23187, dopamine, saponin, 4- $\beta$-phorbol12-myristate-13-acetate (PMA), 4- $\alpha$-phorbol, bovine serum albumin (essentially fatty acid-free), pertussis toxin, staurosporine, forskolin, and isobutylmethylxanthine were from Sigma (France). 1-O-octadecyl-2-Omethyl-sn-glycero-3-phosphorylcholine (OMPC) was obtained from Biomol Research Laboratories (Plymouth Meeting, PA); guanosine-5' $O$-(3-thiotrisphosphate) (GTP- $\gamma$-S), from Boehringer Mannheim (France); fura-2 acetoxymethyl ester, from Molecular Probes (Eugene, $\mathrm{OR}$; and Rp-adenusine-cAMP monophosphothioate (Rp-cAMPS), from Research Biochemicals (Natick, MA). Quinpirole was a generous gift of Eli Lilly (Indianapolis, IN), and raclopride, of Astra (Södertalje, Sweden). Verrucosin B was purified from the marine mollusk Doris verrucosa as described (Cimino et al., 1988).

\section{Results}

Phorbol ester switches preferential $D_{2}$ receptor signaling from inhibition of adenylyl cyclase to facilitation of $A A$ release

In $\mathrm{CHO}\left(\mathrm{D}_{2}\right)$ cells, dopamine enhanced the release of ${ }^{3} \mathrm{H}-\mathrm{AA}$ stimulated by agents that elevate intracellular $\mathrm{Ca}^{2+}$, such as the $\mathrm{Ca}^{2+}$ ionophore $\mathrm{A} 23187$ (Fig. 1a), and inhibited the accumulation of cAMP stimulated by forskolin (Fig. $1 b$ ). Concentrations of dopamine that produced half-maximal potentiation $\left(\mathrm{EC}_{50}\right)$ of ${ }^{3} \mathrm{H}$-AA release and half-maximal inhibition $\left(\mathrm{IC}_{50}\right)$ of cAMP accumulation were $24 \mathrm{nM}$ and $5 \mathrm{nM}$, respectively. When cells were stimulated with dopamine in the presence of the PKC activator PMA (100 $\mathrm{nM}$ ), the resulting potentiation of A23187evoked ${ }^{3} \mathrm{H}$-AA release was much greater than with dopamine alone (Fig. 1a). Incubation with PMA affected both the maximal response to dopamine (from $300 \%$ to $700 \%$ of A23187-evoked ${ }^{3} \mathrm{H}-\mathrm{AA}$ release) and its $\mathrm{EC}_{50}$ (from $24 \mathrm{~nm}$ to $8 \mathrm{~nm}$ ). In contrast with this facilitating action on AA release, treatment with PMA decreased the inhibition of adenylyl cyclase activity caused by stimulation of $\mathrm{D}_{2}$ receptors (Fig. $1 b$ ). In the presence of phorbol ester, maximal dopamine-induced inhibition of cAMP accumulation was reduced from $70 \%$ to $50 \%$ of control and its $\mathrm{IC}_{\text {so }}$ was increased from $5 \mathrm{~nm}$ to $30 \mathrm{~nm}$. PMA was as potent in enhancing dopamine potentiation of ${ }^{3} \mathrm{H}$-AA release $\left(\mathrm{EC}_{50}=8\right.$ nM PMA) as in preventing its inhibition of adenylyl cyclase $\left(\mathrm{EC}_{50}=5 \mathrm{~nm}\right)$ (Fig. $1 c$ ).

In unstimulated $\mathrm{CHO}\left(\mathrm{D}_{2}\right)$ cells, PMA had no effect on either cAMP formation or ${ }^{3} \mathrm{H}$-AA release (not shown). Likewise, levels of $\mathrm{AAMP}$ measured in the presence of PMA $(1 \mu \mathrm{M})$ plus forskolin $(10 \mu \mathrm{M})$ were $107 \pm 11 \%$ of those found with forskolin alone (mean \pm SEM, $n=4$ ), indicating that the phorbol ester exerted no direct action on adenylyl cyclase activity. By contrast, PMA enhanced release of ${ }^{3} \mathrm{H}$-AA evoked by $\mathrm{Ca}^{2+}$ ionophore $\mathrm{A} 23187$ in the absence of $\mathrm{D}_{2}$ receptor stimulation (Figs. $1 a, 2 A$ ). The result confirms previous reports showing that phorbol esters potentiate croked ${ }^{3} \mathrm{H}$-AA relcase from $\mathrm{CHO}$ cells, likely by stimulating phosphorylation of cytosolic phospholipase $\mathrm{A}_{2}$ (cPLA $)_{2}$ (Felder et al., 1991; Kanterman et al., 1991; Lin et al., 1992). However, even at maximal concentrations of drug $(0.1-$ $1 \mu \mathrm{M})$, the effect of PMA on A23187-evoked ${ }^{3} \mathrm{H}$-AA release was markedly weaker than that produced by stimulating $D_{2}$ receptors with quinpirole, $\mathrm{a}_{2}$ receptor agonist (Fig. 2), or with dopamine (not shown). Furthermore, when PMA and quinpirole were combined, the resulting ${ }^{3} \mathrm{H}-\mathrm{AA}$ release was much greater than the sum of the effects of the two drugs used separately (Fig. 2). The greater-than-additive release produced by concomitant activation of $D_{2}$ receptors and PKC suggests that the two stimuli may act through independent pathways to cause a synergistic facilitation of $\mathrm{CPLA}_{2}$ activity.

\section{The effects of $P M A$ on $D_{2}$ receptor signaling are mediated by $P K C$}

The actions of PMA on $\mathrm{D}_{2}$ receptor signaling were produced through activation of $\mathrm{PKC}$. In agreement, we observed that (1) PMA enhanced ${ }^{3} \mathrm{H}-\mathrm{AA}$ release and prevented adenylyl cyclase inhibition with similar potencies (Fig. 1c); (2) the inactive analog 4- $\alpha$-phorbol-12,13-didecanoate was ineffective (Table 1); (3) the effects of PMA on both cAMP accumulation and ${ }^{3} \mathrm{H}$-AA release were prevented by the PKC inhibitors staurosporine $(0.5 \mu \mathrm{M})$ and OMPC (50 $\mu \mathrm{M})$ (Helfman et al., 1983); (4) a non-phorbol ester PKC activator, the marine diterpene verrucosin $B$ (De Petrocellis et al., 1991), enhanced ${ }^{3} \mathrm{H}-\mathrm{AA}$ release to an extent 


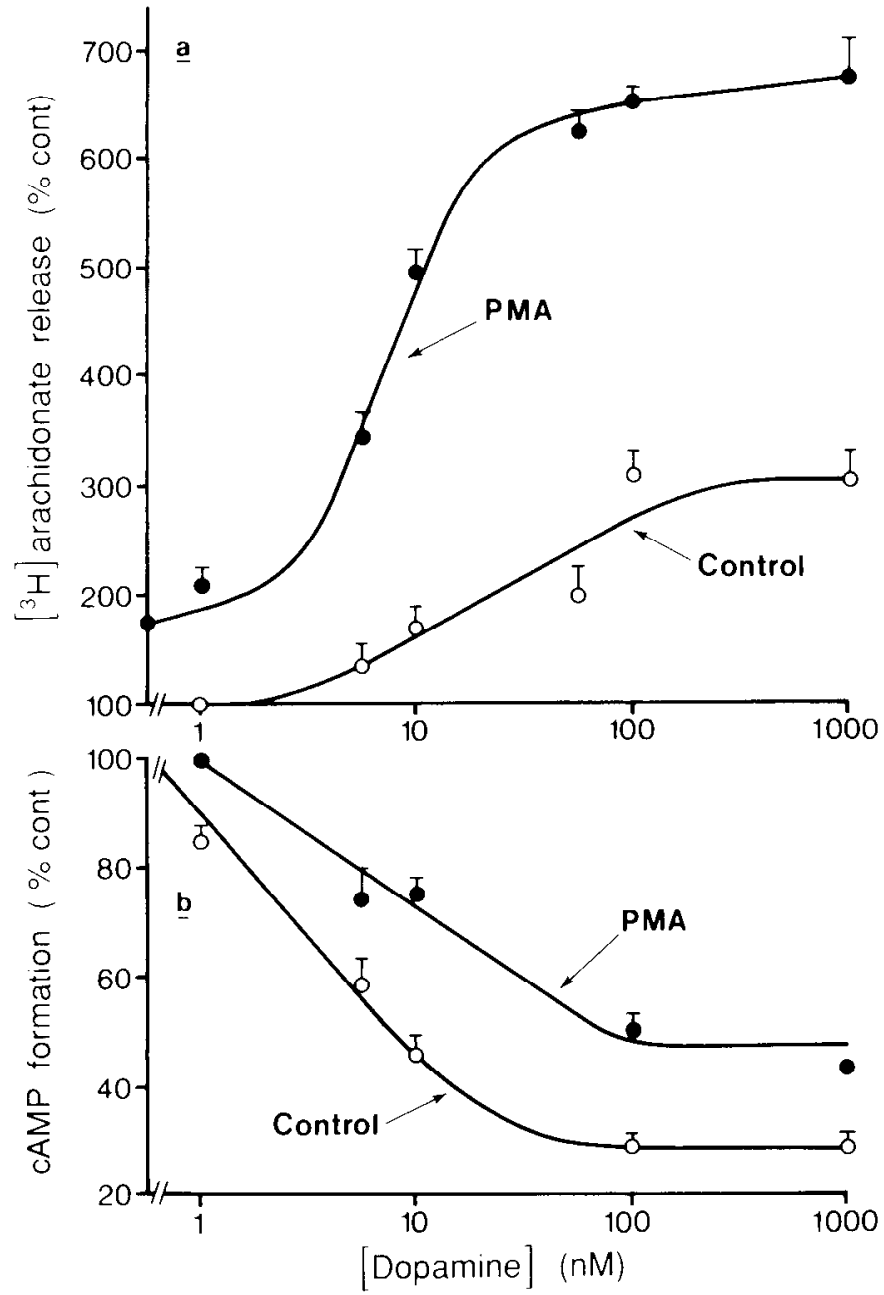

similar to PMA (Table 1). In the absence of PMA, staurosporine did not affect $D_{2}$ receptor-dependent inhibition of adenylyl cyclase (Table 1). By contrast, the potentiation of ${ }^{3} \mathrm{H}-\mathrm{AA}$ release produced by $\mathrm{D}_{2}$ receptor stimulation was reduced by $\mathrm{PKC}$ inhibitors (Table 1), confirming that activity of this protein kinase is an important requirement in the receptor-dependent activation of cPLA (Felder et al., 1991; Kanterman et al., 1991; Lin et al., 1992).

Application of 8-bromo-cAMP, a membrane-permeant cAMP analog, enhances $\mathrm{D}_{2}$ receptor-dependent potentiation of ${ }^{3} \mathrm{H}-\mathrm{AA}$ release in $\mathrm{CHO}\left(\mathrm{D}_{2}\right)$ cells (Piomelli et al., 1991). To examine whether enhancement of ${ }^{3} \mathrm{H}$-AA release by $\mathrm{PMA}$ resulted from increased cAMP levels (subsequent to its effect on $D_{2}$ receptorinduced inhibition of adenylyl cyclase), we stimulated cells in the presence of Rp-cAMPS, a selective cAMP antagonist (Rothermel et al., 1984). Rp-cAMPS $(20 \mu \mathrm{M})$ did not affect ${ }^{3} \mathrm{H}$-AA release produced by $P M A$ plus quinpirole, a $\mathrm{D}_{2}$ receptor agonist, suggesting that cAMP does not participate in this response (Table 1).

\section{$P M A$ has no effect on $D_{2}$ receptor binding}

In membranes prepared from rat striatum, phosphorylation by purified PKC was shown to reduce the modulatory effect of GTP- $\gamma-\mathrm{S}$ on ${ }^{3} \mathrm{H}$-spiperone binding, suggesting that PKC-mediated mechanisms may regulate striatal $D_{2}$ receptor function

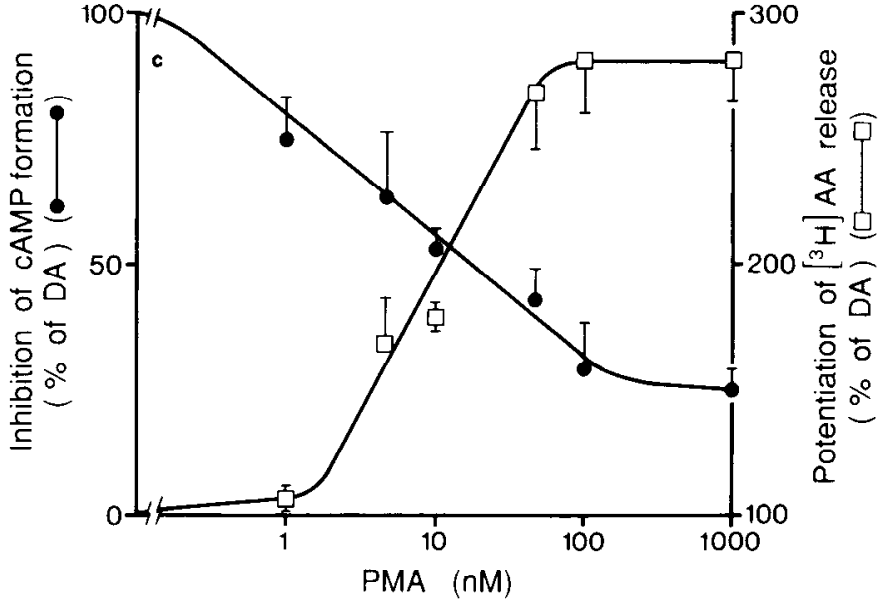

Figure 1. Effects of the PKC activator PMA on intracellular signaling in $\mathrm{CHO}$ cells expressing the $\mathrm{D}$, receptor subtype. $a$, PMA potentiates $\mathrm{D}_{2}$-dependent facilitation of ${ }^{3} \mathrm{H}-\mathrm{AA}$ release. $\mathrm{CHO}\left(\mathrm{D}_{2}\right)$ cells, labeled by incubation with ${ }^{3} \mathrm{H}-\mathrm{AA}$, were incubated for $30 \mathrm{~min}$ with the $\mathrm{Ca}^{2+}$ ionophore A23187 $(2 \mu \mathrm{M})$, plus dopamine at the indicated concentrations, in the absence (open circles) or in the presence (solid circles) of PMA $(0.1 \mu \mathrm{M})$. Results are expressed as percentage of the release evoked by stimulation with A23187 $(2 \mu \mathrm{M})(297 \pm 55 \mathrm{cpm} /$ well, $n=6) . b$, PMA impairs $\mathrm{D}_{2}$-dependent inhibition of cAMP accumulation. Cells were incubated for $20 \mathrm{~min}$ with the adenylyl cyclase activator forskolin (10 $\mu \mathrm{M}$ ), plus dopamine, in the absence (open circles) or presence (solid circles) of PMA $(0.1 \mu \mathrm{M}, 10 \mathrm{~min}$ preincubation). Results are expressed as percentage inhibition of forskolin-stimulated cAMP level $(51 \pm 9$ $\mathrm{fmol} /$ well, $n=6$ ). $c$, Concentration-dependent effects of PMA on both $\mathrm{D}_{2}$-dependent facilitation of ${ }^{3} \mathrm{H}$-AA release (open squares) and inhibition of cAMP accumulation (solid circles). In both cases, results are expressed as percentage of the response elicited by dopamine $(50 \mathrm{nM})$.

(Rugue et al., 1990). Therefore, we examined the effects of PMA on $\mathrm{D}_{2}$ receptor binding in $\mathrm{CHO}\left(\mathrm{D}_{2}\right)$ cells, using the highly selective $\mathrm{D}_{2}$ receptor ligand ${ }^{125}$ I-iodosulpride (Martres et al., 1985). Treating cells with PMA $(1 \mu \mathrm{M})$ had no effect either on the displacement of ${ }^{125}$ I-iodosulpride binding by dopamine, measured subsequently in isolated membranes, or on the modulation of this binding by GTP- $\gamma-\mathrm{S} . B_{\max }$ values were (in pmol/mg protein) $1.36 \pm 0.12$ in control and $1.37 \pm 0.13$ in PMA-treated cells. Likewise, $\mathrm{EC}_{50}$ values for GTP- $\gamma-\mathrm{S}$ in shifting the agonist competition curve from complex to monophasic remained unchanged (14 $\pm 3 \mathrm{~nm}$ in control and $19 \pm 8 \mathrm{~nm}$ in PMA-treated cells, $n=4$ or 5$)$.

$P K C$ enables the productive coupling of $D_{2}$ receptors to $C P L_{2}$ in $C H O$ cells expressing the $D_{2(4 I 5)}$ receptor subtype

The effects of PMA on $\mathrm{D}_{2}$-dependent potentiation of $\mathrm{CPLA}_{2}$ and inhibition of adenylyl cyclase activities were further examined using a clonal line of $\mathrm{CHO}$ cells expressing the human $\mathrm{D}_{2(415)}$ receptor, $\mathrm{CHO}\left(\mathrm{D}_{2(415)}\right)$. This isoform, derived from alternative splicing of the $\mathrm{D}_{2}$ receptor gene transcript (Schwartz et al., 1992), also termed $D_{2 S}$, differs from the $D_{2(444)}$ (here referred to as $D_{2}$ ) in that it lacks a segment of 29 amino acid residues located within the third putative cytoplasmic loop of the protein, a domain that is thought to participate in G-protein coupling and in effector regulation (Dohlman et al., 1991). 


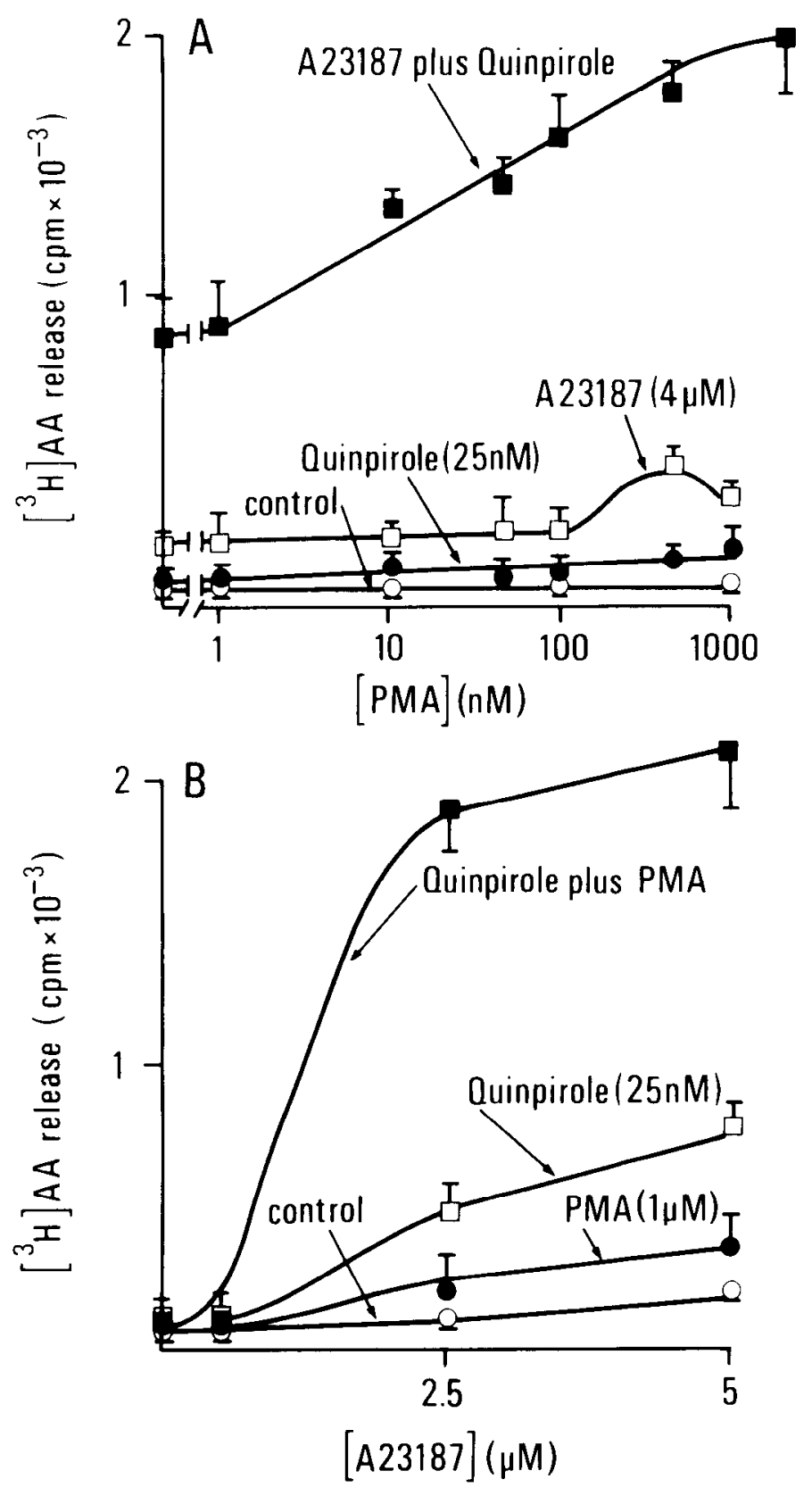

Figure 2. Effects of PMA on stimulated ${ }^{3} \mathrm{H}-\mathrm{AA}$ release from $\mathrm{CHO}\left(\mathrm{D}_{2}\right)$ cells. $A$, Concentration-dependent effects of PMA alone (open squares), PMA in the presence of A23187 (open circles), and PMA in the presence of A23187 plus quinpirole, a $D_{2}$ receptor agonist ( $200 \mathrm{nM}$ ) (solid circles). $B$, Effects of PMA $(1 \mu \mathrm{M})$ on the release of ${ }^{3} \mathrm{H}-\mathrm{AA}$ evoked by $\mathrm{A} 23187$ $(0.5-5 \mu \mathrm{M})$ or by $\mathrm{A} 23187$ plus quinpirole (25 nM).

Cell lines expressing the two splicing variants at similar levels (see Materials and Methods) showed no marked difference either in their endogenous $\mathrm{CPLA}_{2}$, adenylyl cyclase, and PKC activities, or in their ability to respond to the activation of a constitutive, $\mathrm{G}_{\mathrm{i}}$-coupled receptor. In agreement, release of ${ }^{3} \mathrm{H}-\mathrm{AA}$ stimulated by A23187 and accumulation of cAMP stimulated by forskolin were similar in the two cell lines (not shown). Likewise, no significant difference was seen between these cell lines in the ability of PMA to potentiate A23187-evoked ${ }^{3} \mathrm{H}-\mathrm{AA}$ release: in three experiments, potentiations by PMA (50 nM) were $177 \pm 22 \%$ of $\mathrm{A} 23187$-evoked release in $\mathrm{CHO}\left(\mathrm{D}_{2}\right)$ cells
Table 1. The effects of PMA on $D_{2}$ receptor signaling are mediated by PKC

\begin{tabular}{lcl} 
& $\begin{array}{l}\text { Inhibition } \\
\text { of cAMP } \\
\text { accumulation } \\
\text { (\% of }\end{array}$ \\
Treatment & plus quinpirole) & $\begin{array}{l}\text { quinpirole) } \\
\text { puse }\end{array}$ \\
\hline Quinpirole & 100 & 100 \\
+ stauro & $83 \pm 2$ & $109 \pm 9$ \\
+ PMA & $252 \pm 19^{*}$ & $71 \pm 5^{*}$ \\
+ 4- $\alpha$-phorbol & $105 \pm 8$ & $97 \pm 1$ \\
+ PMA/stauro & $61 \pm 4^{*}$ & $92 \pm 5$ \\
+ PMA/OMPC & $130 \pm 5$ & ND \\
+ verrucosin B & $289 \pm 20^{*}$ & ND \\
+ verrucosin B/stauro & $89 \pm 4$ & ND \\
+ PMA/Rp-cAMPs & $284 \pm 22^{*}$ & ND
\end{tabular}

For experiments on ${ }^{3} \mathrm{H}-\mathrm{AA}$ release, prelabeled $\mathrm{CHO}\left(\mathrm{D}_{2}\right)$ cells were incubated for 30 min with A23187 $(4 \mu \mathrm{M})$ and quinpirole $(1 \mu \mathrm{M})$ plus various combinations of the following drugs: PMA $(0.5 \mu \mathrm{M})$; staurosporine (stauro) $(0.5 \mu \mathrm{M})$; OMPC (50 $\mu \mathrm{M})$; verrucosin B $(1 \mu \mathrm{M})$; Rp-cAMPs $(20 \mu \mathrm{M})$. For experiments on cAMP accumulation, cells were incubated for $20 \mathrm{~min}$ with quinpirole $(0.1 \mu \mathrm{M})$ plus the drugs mentioned above. Results are expressed as percentage \pm SEM of the effect produced by quinpirole in 3-10 separate experiments. ND, not determined.

* Statistically different from A23187 plus quinpirole.

and $149 \pm 6 \%$ in $\mathrm{CHO}\left(\mathrm{D}_{2(415)}\right)$ cells. Furthermore, the two lines did not differ in their response to the application of extracellular ATP, which elevates intracellular $\mathrm{Ca}^{2+}$ levels and stimulates cPLA $_{2}$ activity by interacting with constitutive type 2 purinergic receptors, coupled to a $G_{i}$-protein (Gupta et al., 1990). ATP was equally potent $\left(\mathrm{EC}_{50}=5 \mu \mathrm{M}\right)$ in elevating $\mathrm{Ca}^{2+}$ and in evoking ${ }^{3} \mathrm{H}-\mathrm{AA}$ release in both $\mathrm{CHO}\left(\mathrm{D}_{2}\right)$ and $\mathrm{CHO}\left(\mathrm{D}_{2(415)}\right)$ cells.

By contrast, stimulation of $\mathrm{CHO}\left(\mathrm{D}_{2(4 \mid 5)}\right)$ cells with dopamine had little effect on A23187-evoked ${ }^{3} \mathrm{H}$-AA release and only weakly inhibited forskolin-stimulated adenylyl cyclase activity (Fig. 3). Similar results were obtained in four of five $\mathrm{CHO}\left(\mathrm{D}_{2(415)}\right)$ cell lines (not shown), suggesting that the productive coupling of transfected $\mathrm{D}_{2(415)}$ receptors to endogenous cPLA $A_{2}$ and adenylyl cyclase activities was inefficient in these cells. However, when $\mathrm{CHO}\left(\mathrm{D}_{2(4,5)}\right)$ cells were stimulated with a combination of dopamine plus PMA $(0.5 \mu \mathrm{M})$, release of ${ }^{3} \mathrm{H}-\mathrm{AA}$ was enhanced to an extent comparable to that produced by the two agents in $\mathrm{CHO}\left(\mathrm{D}_{2}\right)$ cells (Fig. 3a). Maximal concentrations of PMA (0.1$1 \mu \mathrm{M})$ increased ${ }^{3} \mathrm{H}$-AA release by about sevenfold over dopamine alone. As seen with $\mathrm{CHO}\left(\mathrm{D}_{2}\right)$ cells, PMA diminished dopamine-induced inhibition of adenylyl cyclase in $\mathrm{CHO}\left(\mathrm{D}_{2(4 \mid 5)}\right)$ cells (Fig. $3 b$ ). The results, showing that treatment with a PKC activator fully restores $D_{2}$ receptor-dependent potentiation of ${ }^{3} \mathrm{H}$-AA relcase, suggest that stimulated $\mathrm{PKC}$ activity enables the productive coupling between $\mathrm{D}_{2(4 i 5)}$ receptors and $\mathrm{CPLA}_{2}$ in $\mathrm{CHO}\left(\mathrm{D}_{2(415)}\right)$ cells. They also support the idea that, where coupling to $\mathrm{CPLA}_{2}$ is already functional, as in $\mathrm{CHO}\left(\mathrm{D}_{2}\right)$ cells, $\mathrm{PKC}$ reinforces it, resulting in a much greater receptor-dependent facilitation of $\mathrm{Ca}^{2+}$-evoked $\mathrm{AA}$ release.

PMA exerts opposing actions on the sensitivities of adenylyl cyclase and $\mathrm{cPLA} \mathrm{A}_{2}$ to $\mathrm{GTP}-\gamma-\mathrm{S}$

To examine further the actions of $\mathrm{PKC}$ on $\mathrm{D}_{2}$ receptor signaling, we used stably permeabilized $\mathrm{CHO}\left(\mathrm{D}_{2}\right)$ cells, previously labeled by incubation with ${ }^{3} \mathrm{H}$-AA. When the cells were exposed to an extracellular medium containing saponin $(50 \mu \mathrm{g} / \mathrm{ml})$ and no added $\mathrm{Ca}^{2+}$, they released ${ }^{3} \mathrm{H}-\mathrm{AA}$ in the medium in a $\mathrm{Ca}^{2+}$ 

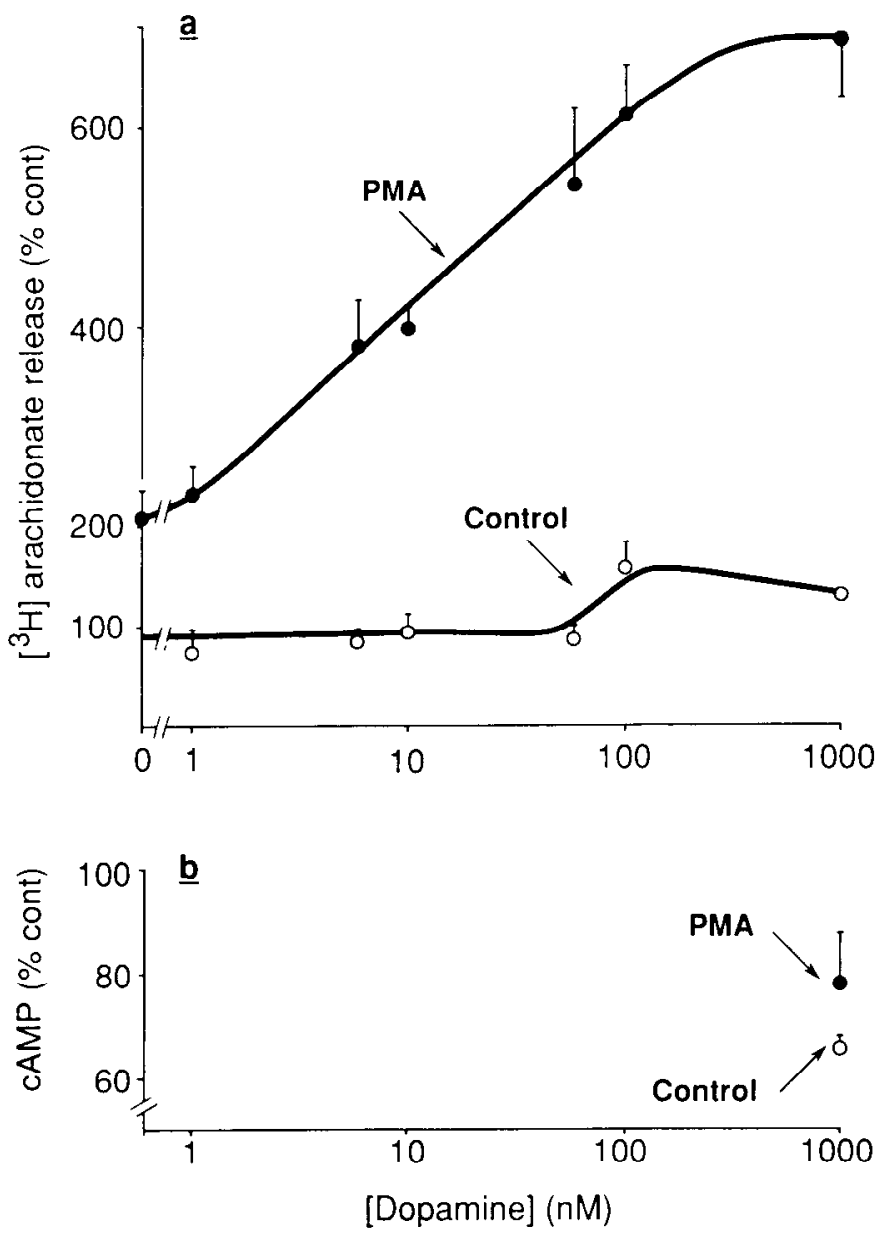

Figure 3. Effects of PMA on cAMP accumulation and ${ }^{3} \mathrm{H}-\mathrm{AA}$ release from $\mathrm{CHO}$ cells expressing the $\mathrm{D}_{2(415)}$ receptor isoform, an alternative splicing variant of the $D_{2}$ receptor. $a$, PMA enables $D_{2}$-dependent facilitation of ${ }^{3} \mathrm{H}$-AA release in $\mathrm{CHO}\left(\mathrm{D}_{2(415)}\right)$ cells. Cells were labeled by incubation with ${ }^{3} \mathrm{H}-\mathrm{AA}$, and incubated for $30 \mathrm{~min}$ with A23187 $(2 \mu \mathrm{M})$ plus dopamine, in the absence (open circles) or in the presence (solid circles) of PMA $(0.1 \mu \mathrm{M})$. Results are expressed as percentage of release evoked by stimulation with A23187 (255 $\pm 17 \mathrm{cpm} /$ well, $n=19) . b$, Weak $\mathrm{D}_{2}$-dependent inhibition of cAMP accumulation in $\mathrm{CHO}\left(\mathrm{D}_{2 \mathrm{~B}(415)}\right)$ cells, and its prevention by PMA. Cells were incubated for 20 min with the adenylyl cyclase activator forskolin $(10 \mu \mathrm{M})$, plus dopamine, in the absence (open circles) or in the presence (solid circles) of PMA $(0.1 \mu \mathrm{M}$, $10 \mathrm{~min}$ preincubation). Results are expressed as percentage inhibition of forskolin-stimulated cAMP level (99 $\pm 12 \mathrm{fmol} /$ well, $n=3)$.

dependent manner, as shown by the ability of EGTA ( $5 \mathrm{~mm})$ to inhibit the release (from $1669 \pm 86$ to $1209 \pm 42 \mathrm{cpm} /$ well; $p$ $<0.05$ by paired $t$ test, $n=12$ ). In additional experiments, quinpirole $(5 \mu \mathrm{M})$ was found to produce a small but significant increase in ${ }^{3} \mathrm{H}-\mathrm{AA}$ release, which was markedly enhanced by coapplication of GTP- $\gamma-\mathrm{S}(100 \mu \mathrm{M})$, a nonhydrolyzable GTP analog, and inhibited by treatment with either raclopride, a $D_{2}$ receptor antagonist ( $5 \mu \mathrm{M})$ (Table 2$)$, EGTA ( $5 \mathrm{mM}$ ), or pertussis toxin $(200 \mathrm{ng} / \mathrm{ml} ; 4 \mathrm{hr}$ ) (not shown). Alone, GTP- $\gamma-\mathrm{S}$ had no effect on ${ }^{3} \mathrm{H}-\mathrm{AA}$ release (Table 2 ).

The ability of GTP- $\gamma-S$ to synergize with $D_{2}$ receptors in potentiating $\mathrm{CPLA}_{2}$ activity in a pertussis toxin-sensitive manner confirms that this response is transduced via a $G_{i}$-protein (Felder et al., 1991; Piomelli et al., 1991). To determine the effects of PMA on this synergistic interaction, saponin-permeabilized $\mathrm{CHO}(\mathrm{D} 2)$ cells were stimulated with $\mathrm{GTP}-\gamma-\mathrm{S}$ in the
Table 2. Effects of quinpirole and GTP- $\gamma-\mathrm{S}$ on $\mathrm{Ca}^{2+}$-evoked ${ }^{3} \mathrm{H}-\mathrm{AA}$ release from permeabilized $\mathrm{CHO}\left(\mathrm{D}_{2}\right)$ cells

\begin{tabular}{ll} 
Treatment & $\begin{array}{l}{ }^{3} \mathrm{H}-\mathrm{AA} \text { release } \\
(\mathrm{cpm} / \text { well })\end{array}$ \\
\hline Control & $2092 \pm 136$ \\
Quinpirole $(5 \mu \mathrm{M})$ & $3089 \pm 386^{*}$ \\
Quinpirole + raclopride $(5 \mu \mathrm{M})$ & $2204 \pm 402$ \\
GTP- $\gamma-\mathrm{S}(100 \mu \mathrm{M})$ & $2284 \pm 289$ \\
GTP- $\gamma-\mathrm{S}+$ raclopride & $2205 \pm 480$ \\
GTP- $\gamma-\mathrm{S}+$ quinpirole & $3875 \pm 457^{*}$
\end{tabular}

Cells were prelabeled with ${ }^{3} \mathrm{H}-\mathrm{AA}$ and stably permeabilized by incubation in a medium containing saponin $(50 \mu \mathrm{g} / \mathrm{ml})$ and no added $\mathrm{Ca}^{2+}$, plus the appropriate drugs $(30 \mathrm{~min}) .{ }^{3} \mathrm{H}$-AA release, measured in samples of the incubation media, is expressed as cpm/well \pm SEM froml a representative experiment carried out in quadruplicate. Similar results were obtained in six additional experiments.

* Statistically different from control.

presence of a concentration of dopamine ( $1 \mu \mathrm{M})$, which alone had little or no effect on ${ }^{3} \mathrm{H}$-AA release. In control incubations, GTP- $\gamma-\mathrm{S}$ synergized with $1 \mu \mathrm{M}$ dopamine to cause ${ }^{3} \mathrm{H}-\mathrm{AA}$ release only at concentrations greater than $50 \mu \mathrm{M}$. However, the inclusion of PMA (50 nM) in the incubation medium resulted both in increased GTP- $\gamma$-S-induced ${ }^{3} \mathrm{H}-\mathrm{AA}$ release and in enhanced sensitivity to the nucleotide analog (Fig. $4 a$ ). Basal, $\mathrm{Ca}^{2+}$ dependent release of ${ }^{3} \mathrm{H}-\Lambda \Lambda$ was also increased by PMA (Fig. $4 a$ ), whereas $\mathrm{Ca}^{2+}$-independent release (in the presence of $5 \mathrm{mM}$ EGTA) remained unaffected (not shown).

Next, we used saponin-permeabilized $\mathrm{CHO}\left(\mathrm{D}_{2}\right)$ cells to investigate the actions of PMA on $\mathrm{D}_{2}$ receptor-dependent inhibition of adenylyl cyclase activity. Forskolin-stimulated release of cAMP in the medium of permeabilized cells was inhibited weakly by dopamine alone $(1 \mu \mathrm{M})(44 \%$ inhibition $)$ and by GTP$\gamma$-S (100 $\mu \mathrm{M})(49 \%$ inhibition) or, more effectively, by a combination of dopamine plus GTP- $\gamma-\mathrm{S}$ (Fig. $4 b$ ). Inclusion of PMA (100 $\mathrm{nm}$ ) in the incubations prevented the ability of low concentrations of GTP- $\gamma$-S to inhibit adenylyl cyclase activity (Fig. $4 b$ ). In the presence of phorbol ester, the concentration of extracellular GTP- $\gamma-S$ necessary to produce maximal inhibition of cAMP accumulation was increased from $10 \mu \mathrm{M}$ to $100 \mu \mathrm{M}$ (Fig. $4 b$ ).

Together, the results obtained with permeabilized $\mathrm{CHO}\left(\mathrm{D}_{2}\right)$ cells suggest that activation of PKC may exert opposing actions on the coupling efficacies of $\mathrm{D}_{2}$ receptors with $\mathrm{CPLA}_{2}$ and adenylyl cyclase by modifying the sensitivities of these signaling pathways to intracellular GTP. These changes in coupling strength may, in turn, underlie the ability of $\mathrm{PKC}$, observed in intact $\mathrm{CHO}\left(\mathrm{D}_{2}\right)$ cells, to direct the preferential signaling at $\mathrm{D}_{2}$ receptors from inhibition of adenylyl cyclase to facilitation of ${ }^{3} \mathrm{H}-\mathrm{AA}$ release.

\section{Discussion}

Our experiments suggest that PKC activity may control effector coupling at the $D_{2}$ receptor by switching it from inhibition of adenylyl cyclase, prevalent in unstimulated cells, to facilitation of AA release, prevalent in cells where PKC has been activated. By remodeling the pattern of intracellular second messengers generated at the $D_{2}$ receptor, such an activity-dependent switch may modify the physiological actions of dopamine in select cells, and potentially represent, if operative in neurons, a novel form of short-term synaptic plasticity. Here we will discuss, first, the possible mechanisms underlying the regulation by $P K C$ of $D_{2}$ 
receptor signaling and, next, its possible relevance and implications for the CNS.

\section{Regulation of $c P L A_{2}$ activity by $G_{i}$-coupled receptors and by protein phosphorylation}

We have shown here that (1) in intact $\mathrm{CHO}\left(\mathrm{D}_{2}\right)$ cells, stimulation of $\mathrm{PKC}$ enhances the $\mathrm{D}_{2}$ receptor-dependent facilitation of AA release; (2) in permeabilized cells, this enhancement is accompanied by a reduction in the concentration threshold of the GTP analog GTP- $\gamma-S$ necessary to potentiate AA release; and (3) stimulation of PKC unmasks the coupling of $D_{2(4 \mid 5)}$ receptors to $\mathrm{CPLA}_{2}$ in a cell line in which this coupling is normally impaired. This impairment was likely caused by inadequate recognition between transfected $D_{2(415)}$ receptor and endogenous G-protein, and does not appear to be consistently linked to the expression of this shorter receptor isoform. In agreement, one of five cell lines tested showed a normal AA response (not shown).

Recent studies on $\mathrm{CHO}$ cells have greatly advanced our understanding of the molecular mechanisms underlying receptoroperated release of AA from membrane phospholipids. It is now recognized that some membrane receptors (e.g., $\mathrm{P}_{2}$-purinergic), acting through a transducing $\mathrm{G}_{\mathrm{i}}$-protein, can induce the $\mathrm{Ca}^{2+}$-dependent translocation of an AA-specific cPLA from the cytosol to the cell membrane, and its subsequent activation (Gupta et al., 1990; Lin et al., 1992). These events are accompanied by increased phosphorylation of $\mathrm{CPLA}_{2}$ on a serine residue, and can be prevented by treatment with PKC inhibitors, suggesting that the protein kinase plays an important role in enabling activation of cPLA $_{2}$ (Kanterman et al., 1991; Lin et al., 1992).

Furthermore, heterologous expression of $\mathrm{D}_{2}$ receptors in $\mathrm{CHO}$ cells has led to the demonstration of an additional mechanism involved in regulating cPLA $\mathrm{C}_{2}$ activity. In transfected $\mathrm{CHO}$ cells, $\mathrm{D}_{2}$ receptor stimulation potently facilitates release of $A A$ evoked either by stimulating constitutive $P_{2}$ receptors or by applying $\mathrm{Ca}^{2+}$ ionophores, but has no effect on basal release (Kanterman et al., 1991; Piomelli et al., 1991). This permissive action of $\mathrm{D}_{2}$ receptors on cPLA $\mathrm{A}_{2}$ activity, which is also seen with other transfected $\mathrm{G}_{\mathrm{i}}$-coupled receptors, such as $\alpha 2$-adrenergic and $\mathrm{m} 2$-muscarinic (Felder et al., 1991), is transduced by a $G_{i}$-protein. In agrecment, the response (1) is prevented by treatment with pertussis toxin (Felder et al., 1991; Piomelli et al., 1991) and (2) is potentiated in permeabilized cells by coapplication of GTP- $\gamma-S$ (present results). Although the identity of the transducing G-protein is not known, this is unlikely to be a $G_{0}$, because these proteins are not expressed in CHO cells (Gupta et al., 1990). In addition, differences in the sensitivity to pertussis toxin suggest that the transducing $G_{i}$ may be distinct from the $G_{i}$ involved in coupling the $\mathrm{D}_{2}$ receptor to inhibition of adenylyl cyclase activity (Felder et al., 1991)

In summary, three factors appear to contribute to receptorstimulated AA release in CHO cells: first, the state of phosphorylation of $\mathrm{CPLA}_{2}$, which may play an enabling role in the enzyme translocation and activation processes; second, the levels of intracellular $\mathrm{Ca}^{2+}$, which may signal the turning on and off of these processes; and third, the presence of an activated $\mathrm{G}_{\mathrm{i}}$-protein, which may exert a permissive action on $\mathrm{cPLA}_{2}$ after translocation of the phospholipase to the membrane, allowing expression of its full catalytic activity. Our findings suggest that PKC may act to reinforce the productive $G_{i}$-mediated coupling between $\mathrm{D}_{2}$ receptors and cPLA$A_{2}$. Potential sites of action for
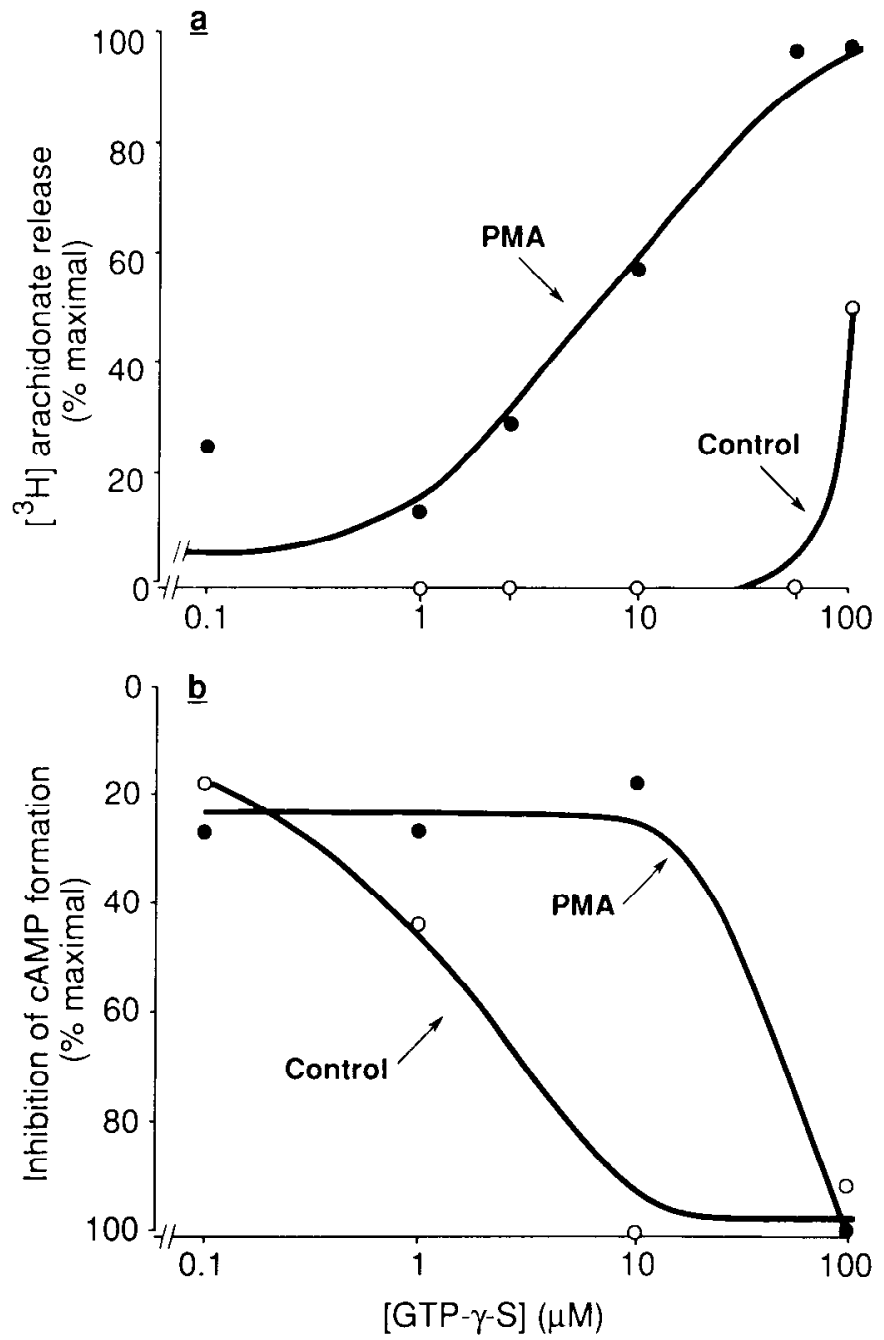

Figure 4. Effects of PMA on the sensitivity of $\mathrm{D}_{2}$ receptor-dependent responses to GTP- $\gamma$-S in permeabilized $\mathrm{CHO}\left(\mathrm{D}_{2}\right)$ cells. $a$, PMA enhances the sensitivity to GTP- $\gamma-S$ of $D_{2}$-dependent facilitation of ${ }^{3} \mathrm{H}$ AA release. Cells were labeled by incubation with ${ }^{3} \mathrm{H}-\mathrm{AA}$, and incubated (30 $\mathrm{min}$ ) in a permeabilizing medium containing saponin $(50 \mu \mathrm{g} / \mathrm{ml})$, plus final concentrations of dopamine $(1 \mu \mathrm{M})$ and GTP- $\gamma-\mathrm{S}(0-100 \mu \mathrm{M})$ in the absence (open circles) or in the presence (solid circles) of PMA $(50 \mathrm{nM})$. Results are from one experiment performed in triplicate (representative of six) and are expressed as percentage of maximal ${ }^{3} \mathrm{H}-\mathrm{AA}$ release after subtraction of $\mathrm{Ca}^{2+}$-independent release (determined in the presence of $5 \mathrm{~mm}$ EGTA). In the experiment shown, maximal ${ }^{3} \mathrm{H}-\mathrm{AA}$ release (obtained in the presence of dopamine, PMA, plus $50 \mu \mathrm{M}$ GTP. $\gamma$-S) was, before background subtraction, $1390 \pm 35 \mathrm{cpm} /$ well. Background release (measured in the presence of $5 \mathrm{~mm}$ EGIA) was $1107 \pm$ $51 \mathrm{cpm} /$ well. $b$, PMA decreases the sensitivity to GTP- $\gamma-S$ of $\mathrm{D}_{2}-\mathrm{me}-$ diated inhibition of cAMP accumulation. Cells were incubated for 20 min in a permeabilizing medium containing saponin plus final concentrations of dopamine $(1 \mu \mathrm{M})$ and GTP- $\gamma-\mathrm{S}(0-100 \mu \mathrm{M})$, in the absence (open circles) or in the presence (solid circles) of PMA (100 nM). IBMX $(0.1 \mathrm{mM})$ and forskolin $(10 \mu \mathrm{M})$ were added to all incubations. Results are from one experiment performed in triplicate (representative of three) and are expressed as percentage of maximal inhibition of cAMP formation. Maximal inhibition (obtained in the presence of dopamine plus $100 \mu \mathrm{M}$ GTP- $\gamma-\mathrm{S}$ ) was $60 \%$ of forskolin alone, which produced a fourto sixfold increase in cAMP levels. In control cells, measured cAMP levels were $2.4-6.3 \mathrm{fmol} / \mathrm{well}$, and in the presence of forskolin, 9-31.7 $\mathrm{fmol} /$ well. 
the protein kinase include the $\mathrm{D}_{2}$ receptor itself, which contains a consensus sequence for PKC phosphorylation (Bunzow et al., 1988); the transducing G-protein, which may be a PKC substrate, as shown for $G_{i 2}$ and $G_{Z}$ (Bushfield et al., 1990; Lounsbury et al., 1991); or the G-protein-regulating protein phosducin (Bauer et al., 1992).

\section{$P K C$ regulates $D_{2}$ receptor-dependent inhibition of $C A M P$ accumulation}

We find that stimulation of PKC reduces the inhibitory action of $D_{2}$ receptor agonists on adenylyl cyclase activity, and that this effect is accompanied by a decreased ability of GTP- $\gamma-S$ to inhibit the cyclase in permeabilized cells. The findings suggest that PKC decreases the GTP sensitivity of the $G_{i}$ subunit linked to adenylyl cyclase, producing, in turn, a weakened coupling of $D_{2}$ receptors with this effector system. In agreement with this possibility, phorbol esters were previously found to reduce receptor-operated inhibition of adenylyl cyclase in platelets and hepatocytes, to stimulate the phosphorylation of $\alpha \mathrm{G}_{\mathrm{i} 2}$, and to reduce its sensitivity to GTP analogs (Jakobs et al., 1985; Katada et al., 1985; Bushfield et al., 1990). A similar mechanism may be operative in CHO cells. If this is the case, it will be interesting to examine whether PKC-mediated phosphorylation of $\alpha \mathrm{G}_{\mathrm{i} 2}$ may also play a role in the enhancement of $\mathrm{cPLA}_{2}$ activity produced by $\mathrm{D}_{2}$ receptor stimulation. Following phosphorylation of $\alpha \mathrm{G}_{\mathrm{i} 2}$, a greater number of $\mathrm{D}_{2}$ receptors, which are thought to be preferentially coupled to this subunit (Senogles et al., 1990), might become free to interact with a distinct, cPLA ${ }_{2}$-linked G-protein, whose existence was suggested by the work of Felder et al. (1991). Alternatively, phosphorylated $\alpha \mathrm{G}_{\mathrm{i} 2}$ may interact better with CPLA $_{2}$ than with adenylyl cyclase. In either case, a single molccular event might affect, concomitantly and in opposite directions, the $\mathrm{D}_{2}$-dependent regulation of both adenylyl cyclase and cPLA $\mathrm{A}_{2}$ activities. This intriguing possibility may find indirect support in two observations: (1) the identical potencies of PMA in enhancing CPLA $_{2}$ potentiation and in decreasing adenylyl cyclase inhibition and (2) the quantitatively similar, but opposing shifts produced by PMA on the sensitivities of $D_{2}$-dependent responses to GTP- $\gamma$-S.

Such a mechanism may also provide a possible explanation for the inability of PMA to affect the GTP- $\gamma-S$ modulation of dopamine binding. Conceivably, no effect of PMA on this binding parameter should be seen if the linkage of $D_{2}$ receptors with $G_{i 2}$ is not affected, or if this linkage is switched onto another G-protein. A corollary to this mechanism is that PMA-induced modifications in adenylyl cyclase and $\mathrm{CPLA}_{2}$ responses should be correlated: any given change produced on the modulation of cPLA $_{2}$ activity should result from a corresponding change in adenylyl cyclase. However, this prediction is not supported by the results obtained with $\mathrm{CHO}\left(\mathrm{D}_{2(415)}\right)$ cells, which show that activation of $\mathrm{PKC}$ may enhance $\mathrm{D}_{2}$-dependent facilitation of cPLA $\mathrm{A}_{2}$ markedly, even when the adenylyl cyclase response is only slightly affected (Fig. 3 ).

Alternative hypothetical models may implicate multiple sites of action for PKC, for example, the concomitant phosphorylation of $\alpha \mathrm{G}_{\mathrm{i} 2}$, leading to decreased cyclase inhibition, and of phosducin, leading to desinhibition of other G-proteins (Bauer et al., 1992). An essential step to allow the testing of these different possibilities will be to determine the nature of the $\mathrm{G}$-protein involved in mediating the actions of $\mathrm{D}_{2}$ receptors on cPLA, activity.

\section{Possible physiological function}

Although the relevance of our findings to the CNS is not yet known, several lines of evidence suggest that coupling mechanisms similar to those observed in transfected $\mathrm{CHO}$ cells may be found in cells constitutively expressing $D_{2}$ receptors, including neurons. $\mathrm{G}_{\mathrm{i}}$-mediated cyclase inhibition is a well-established response produced by $D_{2}$ receptor occupation in various brain areas (Schwartz et al., 1992). Likewise, stimulation of $D_{2}$ receptors was shown to enhance release and metabolism of AA in neural (Hillier et al., 1976) and kidney cells (Huo et al., 1991), while activation of this signaling pathway may participate in certain neuronal $\mathrm{D}_{2}$ responses, such as stimulation of somatostatin release from hypothalamic nerve terminals (Junier et al., 1990).

AA and its metabolites are thought to serve important functions in the nervous system, where they may act both as intracellular second messengers and as local mediators, regulating $\mathrm{K}^{+}$channel opening (Piomelli et al., 1987a,b; Belardetti et al., 1989; Schweitzer et al., 1990), protein kinase activity (McPhail et al., 1984; Piomelli et al., 1989), neurotransmitter release (Linch and Voss, 1990; Freeman et al., 1991), and synaptic plasticity (for review, see Fazeli, 1992). The ability of PKC to amplify $\mathrm{D}_{2}$ receptor signaling via $A A$ release at the expenses of CAMP inhibition may result in the recruitment of a distinct spectrum of biologically active mediators in cells in which PKC activity has been elevated. Through such a mechanism, the physiological responses to dopamine could be regulated dynamically within a neuron by stimuli promoting PKC activation, which include membrane depolarization and $\mathrm{Ca}^{2+}$-mobilizing neurotransmitters (e.g., glutamate acting at metabotropic receptors) (Schoepp et al., 1990).

\section{References}

Bauer PH, Müller S, Puzicha M, Pippig S, Obermaier B, Helmreich EJM, Lohse M (1992) Phosducin is a protein kinase A-regulated G-protein regulator. Nature 358:73-76.

Belardetti F, Campbell WB, Falck JR, Demontis G, Rosolowski M (1989) Products of heme-catalyzed transformation of the arachidonate derivative 12-HPETE open S-type $\mathrm{K}^{+}$channels in Aplysia. Neuron 3:497-505.

Bunzow JR, Van Tol HHM, Grandy DK, Albert P, Salon J, Christie M, Machida CA, Neve KA, Civelli O (1988) Cloning and expression of a rat $\mathrm{D}_{2}$ dopamine receptor cDNA. Nature 336:783-787.

Bushfield M, Murphy GJ, Lavan BE, Parker PJ, Hruby VJ, Milligan G, Houslay MD (1990) Hormonal regulation of $\mathrm{G}_{12} \alpha$-subunit in intact hepatocytes. Biochem J 268:449-457.

Cimino G, Gavagnin M, Sodano G, Puliti R, Mattia CA, Mazzarella L (1988) Verrucosin-A and -B, ichthyotoxic diterpenoic acid glycerides with a new carbon skeleton from dorid nudibranch Doris verrucosa. Tetrahedron 44:2301-2310.

De Petrocellis L, Di Marzo V, Arca B, Gavagnin M, Minei R, Cimino $G$ (1991) The effect of diterpenoidic diacylglycerols on tentacle regeneration in Hydra vulgaris. Comp Biochem Physiol [C] 100:603607.

Di Marzo V, Piomelli D (1992) Participation of prostaglandin $E_{2}$ in dopamine $\mathrm{D}_{2}$ receptor-dependent potentiation of arachidonic acid release. J Neurochem 59:379-382.

Dohlman HG, Thorner J, Caron MG, Lefkowitz RJ (1991) Model systems for the study of seven-transmembrane segment receptors. Annu Rev Biochem 60:653-688.

Fazeli MS (1992) Synaptic plasticity: on the trail of the retrograde messenger. Trends Neurosci 15:115-117.

Felder CC, Williams HL, Axelrod J (1991) A transduction pathway associated with receptors coupled to the inhibitory guanine nucleotide binding protein $G$, that amplifies ATP-mediated arachidonic acid release. Proc Natl Acad Sci USA 88:6477-6480.

Freeman EJ, Damron DS, Terrian DM, Dorman RV (1991) 12-Lipox- 
ygenase products attenuate the glutamate release and $\mathrm{Ca}^{2+}$ accumulation evoked by depolarization of hippocampal mossy fiber nerve endings. J Neurochem 56:1079-1082.

Giros B, Sokoloff P, Martres MP, Riou JF, Emorine LJ, Schwartz JC (1989) Alternative splicing directs the expression of two dopamine $D_{2}$ receptors isoforms. Nature 342:923-926.

Grynkiewicz G, Poenie M, Tsien RY (1985) A new generation of $\mathrm{Ca}^{2+}$ indicators with greatly improved fluorescence properties. J Biol Chem 260:3440-3450.

Gupta SK, Diez E, Heasley LE, Osawa S, Johnson G (1990) A G protein mutant that inhibits thrombin and purinergic receptor activation of phospholipase $A_{2}$. Science 249:662-666.

Helfman DM, Barnes KC, Kinkade JM, Vogler WR, Shoji M, Kuo JF (1983) Phospholipid-sensitive $\mathrm{Ca}^{2+}$-dependent protein phosphorylation system in various types of leukemia cells from human patients and in human leukemia cell lines HL60 and K5623, and its inhibition by alkyl-lysophospholipid. Cancer Res 43:2955-2961.

Hillier K, Roberts PJ, Woollard PM (1976) Catecholamine-stimulated prostaglandin biosynthesis in rat brain synaptosomes. $\mathrm{Br} \mathrm{J}$ Pharmacol $58: 426 \mathrm{P}-427 \mathrm{P}$.

Huo T, Ye MQ, Healy DP (1991) Characterization of a dopamine receptor $\left(\mathrm{DA}_{2 \mathrm{~K}}\right)$ in the kidney inner medulla. Proc Natl Acad Sci USA 88:3170-3174.

Jakobs KH, Bauer S, Watanabe Y (1985) Modulation of adenylate cyclase of human platelets by phorbol ester. Eur J Biochem 151:425430.

Junier MP, Dray F, Blair I, Capdevila J, Dishman E, Falck JR, Ojeda $S$ (1990) Epoxygenase products of arachidonic acid are endogenous constituents of the hypothalamus involved in $D_{2}$ receptor-mediated, dopamine-induced release of somatostatin. Endocrinology 126:15341540.

Kanterman RY, Mahan LC, Briley EM, Monsma FJ, Sibley DR, Axelrod J, Felder CC (1991) Transfected $D_{2}$ receptors mediate the potentiation of arachidonic acid release in Chinese hamster ovary cells. Mol Pharmacol 39:364-369.

Katada T, Gilman AG, Watanabe Y, Bauer S, Jakobs KH (1985) Protein kinase $C$ phosphorylates the inhibitory guanine-nucleotide-binding regulatory component and apparently suppresses its function in hormonal inhibition of adenylate cyclase. Eur J Biochem 151:431437.

Lin L-L, Lin A-Y, Knopf JL (1992) Cytosolic phospholipase $A_{2}$ is coupled to hormonally regulated release of arachidonic acid. Proc Natl Acad Sci USA 89:6147-6151.

Linch MA, Voss KL (1990) Arachidonic acid increases inositol phospholipid metabolism and glutamate release in synaptosomes prepared from hippocampal tissue. J Neurochem 55:215-221.

Lledo PM, Homburger V, Bockaert J, Vincent JD (1992) Differential $G$ protein mediated coupling of $D_{2}$ dopamine receptors to $K^{+}$and $\mathrm{Ca}^{2+}$ currents in rat anterior pituitary cells. Neuron 8:455-463.

Lounsbury KM, Casey PJ, Brass LF, Manning DR (1991) Phosphorylation of $\mathrm{G}$, in human platelets. Selectivity and site of modification. J Biol Chem 266:22051-22056.
Martres MP, Sokoloff P, Delandre M, Schwartz JC, Protais P, Costentin J (1984) Selection of dopamine antagonists discriminating various behavioral responses and radioligand binding sites. Naunyn Schmiedebergs Arch Pharmacol 325:102-115.

Martres MP, Bouthenet ML, Salès N, Sokoloff P, Schwartz JC (1985) Widespread distribution of brain dopamine receptors evidenced with ( ${ }^{25}$ I)iodosulpride, a highly selective ligand. Science 228:752-755.

McPhail LC, Clayton CC, Snyderman R (1984) A potential second messenger role for unsaturated fatty acids: activation of $\mathrm{Ca}^{2}+$-dependent protein kinase. Science 224:622-625.

Nishizuka $Y$ (1988) The molecular heterogeneity of protein kinase $C$ and its implication for cellular regulation. Nature 334:66 I-665.

Piomelli D, Volterra A, Dale N, Siegelbaum SA, Kandel ER, Schwartz JH, Belardetti F (1987a) Lipoxygenase metabolites of arachidonic acid as second messengers for presynaptic inhibition in Aplysia sensory cells. Nature $328: 38-43$.

Piomelli D, Shapiro E, Feinmark SI, Schwartz IH (1987h) Metabolites of arachidonic acid in the nervous system of Aplysia: possible mediators of synaptic modulation. J Neurosci 7:3675-3686.

Piomelli D, Wang JKT, Sihra TS, Nairn AC, Czernik AJ, Greengard $\mathbf{P}$ (1989) Inhibition of $\mathrm{Ca}^{2+} /$ calmodulin-dependent protein kinase II by arachidonic acid and its metabolites. Proc Natl Acad Sci USA 86: $8550-8554$.

Piomelli D, Pilon C, Giros B, Sokoloff P, Martres M-P, Schwartz J-C (1991) Dopamine activation of the arachidonic acid cascade as a basis for $D_{1} / D_{2}$ receptor synergism. Nature 353:164-167.

Rogue P, Zwiller J, Malviya AN, Vincedon G (1990) Phosphorylation by protein kinase $C$ modulates agonist binding to striatal dopamine $\mathrm{D}_{2}$ receptors. Biochem Int 22:575-582.

Rothermel JD, Jastorff B, Parker Botelho LH (1984) Inhibition of glucagon-induced glycogenolysis in isolated rat hepatocytes by the $\mathrm{Rp}$ diastereoisomer of adenosine cyclic 3' 5 ' -phosphorothioate. J Biol Chem 259:8151-8155

Schoepp D, Bockaert J, Sladeczek F (1990) Pharmacological and functional characteristics of metabotropic excitatory amino acid receptors. Trends Pharmacol Sci 11:508-515.

Schwartz JC, Giros B, Martres MP, Sokoloff P (1992) The dopamine receptor family: molecular biology and pharmacology. Semin Neurosci 4:99-108.

Schweitzer P, Madamba S, Siggins GR (1990) Arachidonic acid metabolites as mediators of somatostatin-induced increase of neuronal M-current. Nature 346:464-467.

Senogles SE, Spiegel AM, Padrell E, Iyengar R, Caron MG (1990) Specificity of receptor-G protein interactions. Discrimination of $G$ subtypes by the $\mathrm{D}_{2}$ dopamine receptor in a reconstituted system. J Biol Chem 265:4507-4514.

Sibley DR, Monsma FJ (1992) Molecular biology of dopamine receptors. Trends Pharmacol Sci 13:61-69.

Spiegel AM (1992) G proteins in cellular control. Curr Opin Cell Biol $4: 203-211$. 